\title{
First occurrence of Nyctinomops macrotis (Gray, 1839) (Chiroptera: Molossidae) in Espírito Santo, southeastern
}

\section{Brazil}

\author{
João Paulo Maires Hoppe ${ }^{1 *}$, Mariana Brandão Simões ${ }^{2}$, Vinícius Teixeira Pimenta ${ }^{1}$, Narcisa \\ Imaculada Brant Moreira ${ }^{2}$, Karina Miranda Marinho ${ }^{3}$ and Albert David Ditchfield ${ }^{1}$ \\ 1 Universidade Federal do Espírito Santo, Departamento de Ciências Biológicas, Laboratório de Estudos em Quirópteros. Avenida Marechal \\ Campos, 1468, Maruípe. CEP 29043-900. Vitória, ES, Brazil. \\ 2 Universidade Federal do Espírito Santo, Departamento de Patologia, Laboratório de Parasitologia. Avenida Marechal Campos, 1468, Maruípe. CEP \\ 29043-900. Vitória, ES, Brazil. \\ 3 Instituto de Defesa Agropecuária e Florestal do Espírito Santo, Departamento de Diagnóstico Laboratorial, Rua Raimundo Nonato, 135, Forte São \\ João. CEP 29017-160. Vitória, ES, Brazil. \\ * Corresponding author: jpmhoppe@gmail.com
}

\begin{abstract}
The first occurrence of Nyctinomops macrotis (Gray, 1839) in Espírito Santo state, Southeastern Brazil is reported. A specimen was registered in Vitória, capital of the state, on January 26th, 2011. Morphological aspects of this species are discussed. External and cranial measurements obtained for the specimen and a map with the current known records for the $N$. macrotis in Brazil are provided.
\end{abstract}

The genus Nyctinomops Miller, 1902 can be distinguished from other molossid bats by their large, medially-joined ears; face with flexible and thin hairs; deeply wrinkled upper lips, resulting in vertical grooves; lack of premaxillary region, with upper incisors separated at the base; incisors $1 / 2$; narrow palatal emargination; higher than wide antitragus; and small, rectangular tragus (Kimurai and Jones 1990; Gregorin and Taddei 2002; Eger 2008.). The genus includes four species, one restricted to the south of United States of America and north of Mexico (N. femorosaccus) (Arroyo-Cabrales and Castañeda 2008), and the remaining three occurring in the Neotropical region (N. aurispinosus, N. laticaudatus, and N. macrotis) (Fabián and Gregorin 2007). Nyctinomops macrotis (Gray, 1839) is the largest member of the genus, occurring in Argentina, Bolivia, Brazil, Colombia, Ecuador, Guyana, Peru, Uruguay, and Venezuela (Eger 2008). The species also occurs from southern United States to the province of Chiapas, Mexico (Milner et al. 1990; Reid 2009), and the Greater Antilles islands of Cuba, Dominican Republic and Jamaica (GBIF: http://data.gbif.org). In Brazil, there are records for the Amazonian, Atlantic Forest, Caatinga and Pantanal biomes (Paglia et al. 2012), in the states of Pará, Maranhão, Mato Grosso do Sul, Mato Grosso, Paraná, Rio de Janeiro, São Paulo e Minas Gerais (Peracchi et al. 2011). The records for Santa Catarina (e.g. Vieira 1942; Marinho-Filho 1996) are misidentified Tadarida brasiliensis, Eumops hansae, and Nyctinomops laticaudatus (Eger 2008). Despite its wide distribution, the species is uncommon in surveys, mostly due to the bias of mistnet techniques that undersamples some species, particulary aerial insectivores (Sampaio et al. 2003).

Here, we report the first record of Nyctinomops macrotis in Espírito Santo, southeastern Brazil. We also provide a map with the current known records for Brazil, including the states with confirmed occurrences, but without precise geographical information. The Instituto de Defesa Agropecuária e Florestal do Espírito Santo (IDAF) is a governmental agency that conducts rabies research in domestic and wild mammals in the state. In a joint agreement, IDAF sends bats collected in different localities of the state to Laboratório de Estudos em Quirópteros (LABEQ) at Universidade Federal do Espírito Santo. In January $26^{\text {th }}, 2011$, an adult male specimen of Nyctinomops macrotis was captured at the city of Vitória $\left(20^{\circ} 19^{\prime} 09^{\prime \prime} \mathrm{S}, 40^{\circ} 20^{\prime} 50^{\prime \prime} \mathrm{W}\right)$. The specimen was first fixed in formaldehyde, and then preserved in alcohol 70\% with the skull removed and cleaned, and is now deposited in the bat collection at LABEQ (AD 1096). With this record, $N$. macrotis is now documented in 29 localities in Brazil, as well as for three states where it is registered, but without precise locality information (Figure 1).

The specimen presents all the diagnostic features listed for N. macrotis (Vizotto and Taddei 1973; Lim and Engstrom 2001; Gregorin and Taddei 2002): deeply wrinkled lips resulting in vertical grooves; large, mediallyjoined ears; and forearm greater than $55 \mathrm{~mm}$. The external and cranial measurements (in millimeters) for the specimen were taken with a caliper (precision $=0.01 \mathrm{~mm}$ ), according to Vizotto and Taddei (1973): forearm length = 60.52; palatal length $=9.48$; maxillary toothrow length $=$ 7.92; mandibular toothrow length $=9.35$; breadth across molars $=8.38$; canine breadth $=4.46$; palatal breadth $=4.12$. Unfortunately, the cranium was damaged and measurements of the braincase could not be taken. With this new record, the species richness for bats in Espírito Santo reaches 70 species (Duda et al. 2012; Nogueira et al. 2012). 


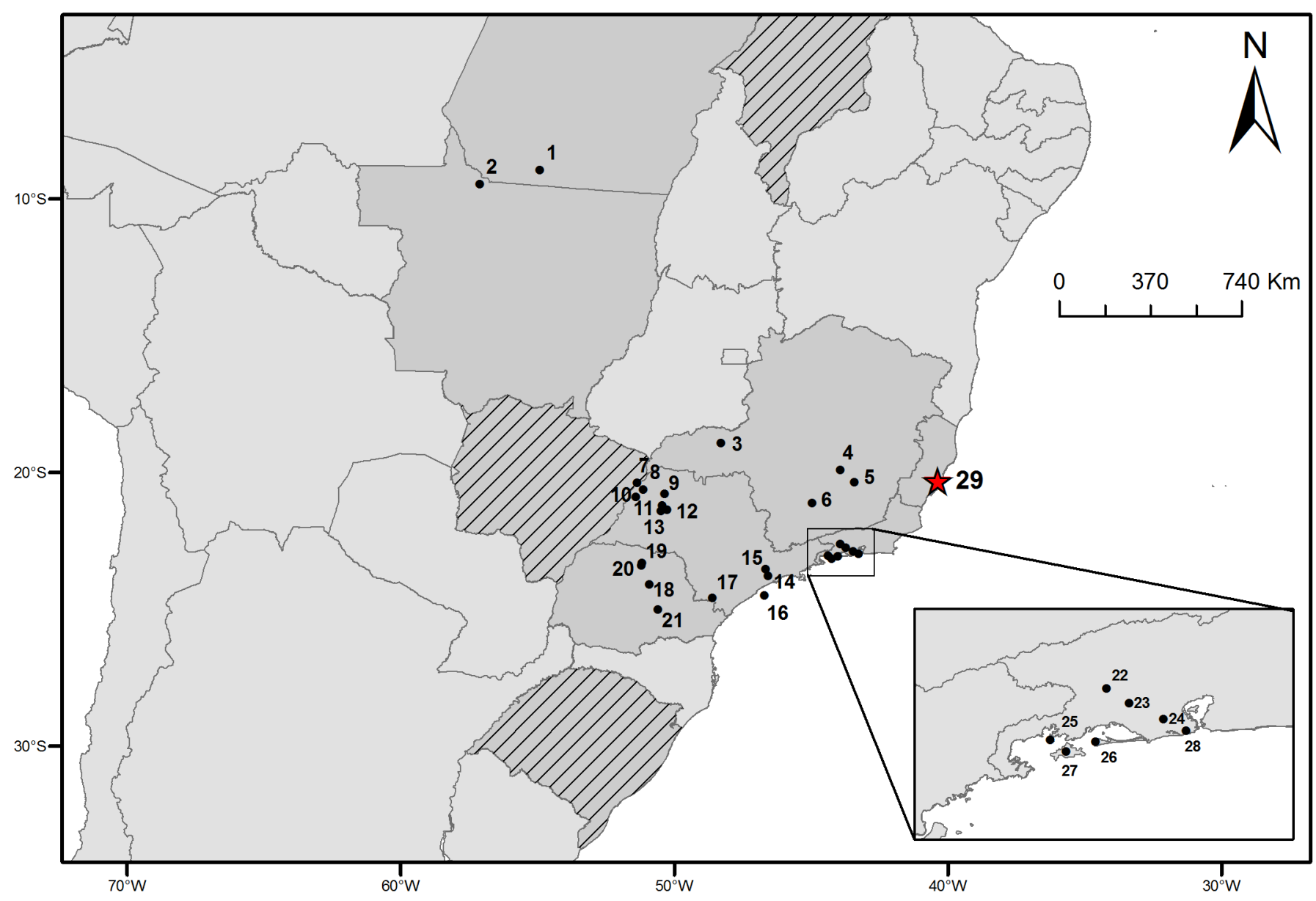

FIGURE 1. Collecting localities of Nyctinomops macrotis in Brazil. Empty dark grey indicates states where a locality with proper vouchers is reported in the literature. Stripped dark grey indicates states where the presence of this bat is reported, but without presenting any vouchers or specifying where the species was sighted. The specific localities are listed: 1. Pará, Cachimbo (08 $57^{\prime} \mathrm{S}, 54^{\circ} 54^{\prime} \mathrm{W}$ ) (Eger 2008); 2. Mato Grosso, Apiacás, Foz do

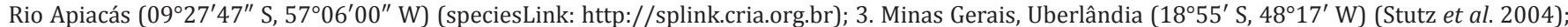

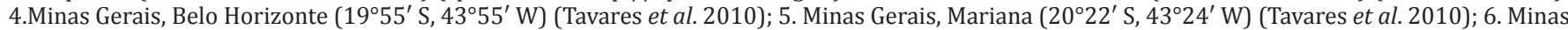

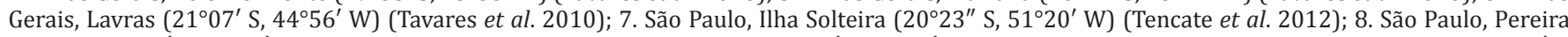
Barreto $\left(20^{\circ} 38^{\prime} \mathrm{S}, 51^{\circ} 07^{\prime} \mathrm{W}\right)$ (Tencate et al. 2012); 9. São Paulo, Castilho $\left(20^{\circ} 47^{\prime} \mathrm{S}, 50^{\circ} 20^{\prime} \mathrm{W}\right)$ (Tencate et al. 2012); 10 . São Paulo, Andradina (20 $54^{\prime} \mathrm{S}$

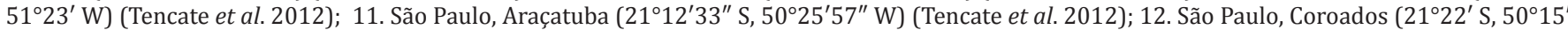

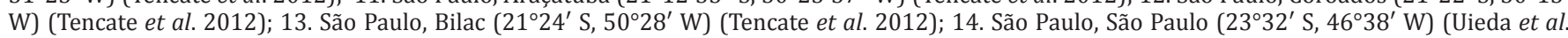

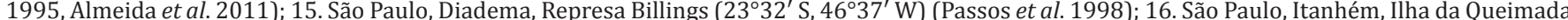

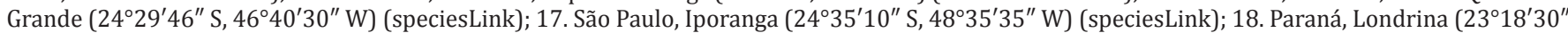
S, $51^{\circ} 09^{\prime} 30^{\prime \prime} \mathrm{W}$ ) (Reis et al. 2002a); 19. Paraná, Londrina ( $23^{\circ} 23^{\prime} 30^{\prime \prime} \mathrm{S}, 51^{\circ} 11^{\prime} 05^{\prime \prime} \mathrm{W}$ ) (Reis et al. 1998); 20. Paraná, Bacia do Rio Tibagi $\left(24^{\circ} 06^{\prime} \mathrm{S}, 50^{\circ} 53^{\prime}\right.$ W) (Reis et al. 2002b); 21. Paraná, Ipiranga $\left(25^{\circ} 00^{\prime} \mathrm{S}, 50^{\circ} 35^{\prime} \mathrm{W}\right.$ ) (GBIF: http://data.gbif.org); 22. Rio de Janeiro, Piraí, Cacaria $\left(22^{\circ} 37^{\prime} 40^{\prime \prime} \mathrm{S}, 43^{\circ} 54^{\prime} 07^{\prime \prime}\right.$ W) (Dias et al. 2010); 23. Rio de Janeiro, Seropédica $\left(22^{\circ} 44^{\prime} 49^{\prime \prime} \mathrm{S}, 43^{\circ} 43^{\prime} 00^{\prime \prime} \mathrm{W}\right.$ ) (Bolzan et al. 2010); 24. Rio de Janeiro, Mangaratiba (22 $52^{\prime} 52^{\prime \prime} \mathrm{S}$,

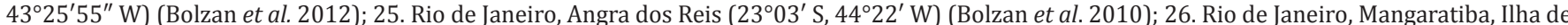
Marambaia ( $23^{\circ} 04^{\prime} \mathrm{S}, 43^{\circ} 53^{\prime} \mathrm{W}$ ) (Costa et al. 2011); 27. Rio de Janeiro, Angra dos Reis, Ilha Grande $\left(23^{\circ} 10^{\prime} 33^{\prime \prime} \mathrm{S}, 44^{\circ} 12^{\prime} 28^{\prime \prime} \mathrm{W}\right)$ (Esbérard et al. 2006); 28. Rio de Janeiro, Rio de Janeiro, Parque da Gávea $\left(23^{\circ} 59^{\prime} 10^{\prime \prime} \mathrm{S}, 43^{\circ} 14^{\prime} 53^{\prime \prime} \mathrm{W}\right)$ (Esbérard and Bergallo 2008); 29 . The new record for Espírito Santo is Vitória $\left(20^{\circ} 19^{\prime} 09^{\prime \prime} \mathrm{S}, 40^{\circ} 20^{\prime} 50^{\prime \prime} \mathrm{W}\right.$ ). States with no vouchers and no specified locality are: Maranhão (Bernard et al. 2011), Mato Grosso do Sul (Cáceres et al. 2008, Alho et al. 2011), and Rio Grande do Sul (Pacheco and Marques 2006, Passos et al. 2010).

ACKNowledgments: We would like to thank the Instituto de Defesa Agropecuária e Florestal do Espírito Santo (IDAF) for providing the specimen. J. Hoppe received an undergraduate scholarship from Fundo de Amparo à Ciência e Tecnologia do Espírito Santo (FAPES). The specimen was collected under licence number 14592-1 from Instituto Brasileiro do Meio Ambiente e dos Recursos Naturais Renováveis (IBAMA).

\section{LITERATURE CITED}

Alho, C.J.R., E. Fischer, L.F. Oliveira-Pissini and C.F. Santos. 2011. Batspecies richness in the Pantanal floodplain and its surrounding uplands. Brazilian Journal of Biology 71(1, suppl.): 311-320.

Almeida, M.F., L.F.A. Martorelli, M.M. Sodré, A.P.A.G. Kataoka, A.R. Rosa, M.L. Oliveira and E. Amatuzzi. 2011. Rabies diagnosis and serology in bats from the state of São Paulo, Brazil. Revista da Sociedade Brasileira de Medicina Tropical 44(2): 140-145.

Arroyo-Cabrales, J. and T.A. Castañeda. 2008. Nyctinomops femorosaccus, in: IUCN 2013. IUCN Red List of Threatened Species. Version 2013.2. Accessible at www.iucnredlist.org. Captured on 10 February 2014.

Bernard, E., V.C. Tavares and E. Sampaio. 2011. Compilação atualizada das espécies de morcegos (Chiroptera) para a Amazônia Brasileira. Biota Neotropica 11(1): 35-46.
Bolzan, D.P., E.C. Lourenço, L.M. Costa, J.L. Luz, T.J. Nogueira, D. Dias, C.E.L. Esbérard and A.L. Peracchi. 2010. Morcegos da região da Costa Verde e adjacências, litoral sul do estado do Rio de Janeiro. Chiroptera Neotropical 16(1): 585-594

Cáceres, N.C., A.P. Carmignotto, E. Fischer and C.F. Santos. 2008. List of species. Mammals from Mato Grosso do Sul, Brazil. Check List 4(3): 321-335.

Costa, L.M., E.C. Lourenço, J.L. Luz, A.P.F. Carvalho and C.E.L. Esbérard. 2011. Activity of two species of free-tailed bats over a stream in southeastern Brazil. Acta Chiropterologica 13(2): 405-409.

Dias, D., S.N. Pereira, A.C.S. Maas, M.A. Martins, D.P. Bolzan and A.L. Peracchi. 2010. Quirópteros das regiões Centro-Sul e Médio Paraíba do estado do Rio de Janeiro (Mammalia, Chiroptera). Chiroptera Neotropical 16(1): 579-585.

Duda, R., J. Dalapicolla and L.P. Costa. 2012. First record of the smoky bat Furipterus horrens (F. Cuvier, 1828) (Mammalia: Chiroptera) in the state of Espírito Santo, southeastern Brazil. Check List 8(6): 13621464.

Eger, J.L. 2008 [2007]. Family Molossidae P. Gervais, 1856; pp. 399439, in: A.L. Gardner (ed.). Mammals of South America. Marsupials, xenarthrans, shrews, and bats. Volume 1. Chicago: The University of 
Chicago Press.

Esbérard, C.E.L. and H.G. Bergallo. 2008. Do bigger bats need more time to forage? Brazilian Journal of Biology 68(4): 819-822.

Esbérard, C.E.L., T.J. Nogueira, J.L. Luz, G.G.S. Melo, R. Mangolin, N. Jucá, D.S.L. Raíces, M.C. Enrici and H. Bergallo. 2006. Morcegos da Ilha Grande, Angra dos Reis, RJ, Sudeste do Brasil. Revista Brasileira de Zoociências 8(2): 147-153.

Fabián, M.E. and R. Gregorin. 2007. Família Molossidae; pp. 149-167, in: N.R. Reis, A.L. Peracchi, W.A. Pedro and I.P. Lima (eds.). Morcegos do Brasil. Londrina: Editora da Universidade Estadual de Londrina.

Gregorin, R. and V.A. Taddei. 2002. Chave artificial para identificação de molossídeos brasileiros (Mammalia, Chiroptera). Mastozoología Neotropical 9(1): 13-32.

Kimurai, A. and J.K. Jones Jr. 1990. Nyctinomops femorosaccus. Mammalian Species 349: 1-5.

Lim, B.K. and M.D. Engstrom. 2001. Species diversity of bats (Mammalia: Chiroptera) in Iwokrama Forest, Guyana, and the Guianan subregion: implications for conservation. Biodiversity and Conservation 10: 613-657.

Marinho-Filho, J. 1996. Distribution of bat diversity in the southern and southeastern brazilian Atlantic Forest. Chiroptera Neotropical 2(2): 51-54.

Milner, J., C. Jones and J.K. Jones Jr. 1990. Nyctinomops macrotis. Mammalian species 351: 1-4.

Nogueira, M.R., I.P. Lima, A.L. Peracchi and N.B. Simmons. 2012. New genus and species of nectar-feeding bat from the Atlantic Forest of southeastern Brazil (Chiroptera: Phyllostomidae: Glossophaginae). American Museum Novitates 3747: 1-30.

Pacheco, S.M. and R.V. Marques. 2006. Conservação de morcegos no Rio Grande do Sul; pp. 91-106, in: T.R.O. Freitas, E. Vieira, S.M. Pacheco and A. Christoff (ed.). Mamíferos do Brasil: genética, sistemática, ecologia e conservação. São Carlos: Suprema Gráfica e Editora.

Paglia, A.P., G.A.B. Fonseca, A.B. Rylands, G. Herrmann, L.M.S. Aguiar, A.G. Chiarello, Y.L.R. Leite, L.P Costa, S. Siciliano, M.C.M. Kierulff, S.L. Mendes, V. C. Tavares, R.A. Mittermeier and J.L. Patton. 2012. Lista anotada dos mamíferos do Brasil / Annotated checklist of Brazilian mammals. 2nd Edition. Occasional Papers in Conservation Biology 6: $1-76$.

Passos, E.C., M.L. Carrieri, E. Dainovskas, M. Camara and M.M.S Silva. 1998. Isolamento do vírus rábico em morcego insetívoro, Nyctinomops macrotis, no município de Diadema, SP (Brasil). Revista de Saúde Pública 32(1): 74-76.

Passos, F.C., J.M.D. Miranda, I.P. Bernardi, N.Y. Kaku-Oliveira and L.C. Munster. 2010. Morcegos da região Sul do Brasil: análise comparativa da riqueza de espécies, novos registros e atualizações nomenclaturais (Mammalia, Chiroptera). Iheringia, Série Zoologia 100(1): 25-34.
Peracchi, A.L., I.P. Lima, N.R. Reis, M.R. Nogueira and H.O. Filho. 2011. Ordem Chiroptera; pp. 155-234, in: N.R. Reis, A.L. Peracchi, W.A. Pedro and I.P. Lima (eds.). Mamíferos do Brasil, $2^{-}$ed. Londrina: Editora da Universidade Estadual de Londrina.

Reid, F.A. 2009. A Field Guide to the Mammals of Central America and Southeast Mexico. Oxford University Press: 384 pp.

Reis, N.R., I.P. Lima and A.L. Peracchi. 2002a. Morcegos (Chiroptera) da área urbana de Londrina, Paraná, Brasil. Revista Brasileira de Zoologia 19(3): 739-746.

Reis, N.R., A.L. Peracchi and I.P. Lima. 2002b. Morcegos da bacia do rio Tibagi; pp. 251-270, in: M.E. Medri, E. Bianchini, O.A. Shibatta and J.A. Pimenta (eds.). A bacia do rio Tibagi. Londrina: Editora da Universidade Estadual de Londrina.

Reis, N.R., A.L. Peracchi, I.P. Lima, M.L. Sekiama and V.J. Rocha. 1998. Updated list of the Chiropterians of the city of Londrina, Paraná, Brazil. Chiroptera Neotropical 4(2): 96-98.

Sampaio, E.M., E.K.V. Kalko, E. Bernard, B. Rodríguez-Herrera and C.O. Handley Jr. 2003. A biodiversity assessment of bats (Chiroptera) in a tropical lowland rainforest of Central Amazonia, including methodological and conservation considerations. Studies on Neotropical Fauna and Environment 38(1): 17-31.

Stutz, W.H., M.C. Albuquerque, W. Uieda, E.M. Macedo and C.B. França. 2004. Updated list of bats from Uberlandia, state of Minas Gerais, southeastern Brazil. Chiroptera Neotropical 10(1-2): 188-190.

Tavares, V.C., L.M.S. Aguiar, F.A. Perini, F.C. Falcão and R. Gregorin. 2010. Bats of the state of Minas Gerais, southeastern Brazil. Chiroptera Neotropical 16(1): 675-705.

Tencate, L.C., C.V. Táparo, C. Carvalho, S.M.G. Bosco, L.H. Queiroz, D.C. Silva, S.H.V. Perri and M. Marinho. 2012. Estudo da microbiota fúngica gastrintestinal de morcegos (Mammalia, Chiroptera) da região noroeste do estado de São Paulo: potencial zoonótico. Brazilian Journal of Veterinary Research and Animal Science 49(2): 146-152.

Uieda, W., N.M.S. Harmani and M.M.S. Silva. 1995. Raiva em morcegos insetívoros (Molossidae) do Sudeste do Brasil. Revista de Saúde Pública 29(5): 393-397.

Vieira, C.O.C. 1942. Ensaio monográfico sobre os quirópteros do Brasil. Arquivos de Zoologia do Estado de São Paulo 3: 219-471.

Vizotto, L.D. and V.A. Taddei. 1973. Chave para determinação de quirópteros brasileiros. São José do Rio Preto: Universidade Estadual Paulista. 72 pp.

RECEIVED: October 2013

ACCEPTED: February 2014

Published ONLINE: May 2014

Editorial Responsibility: Paúl M. Velazco 